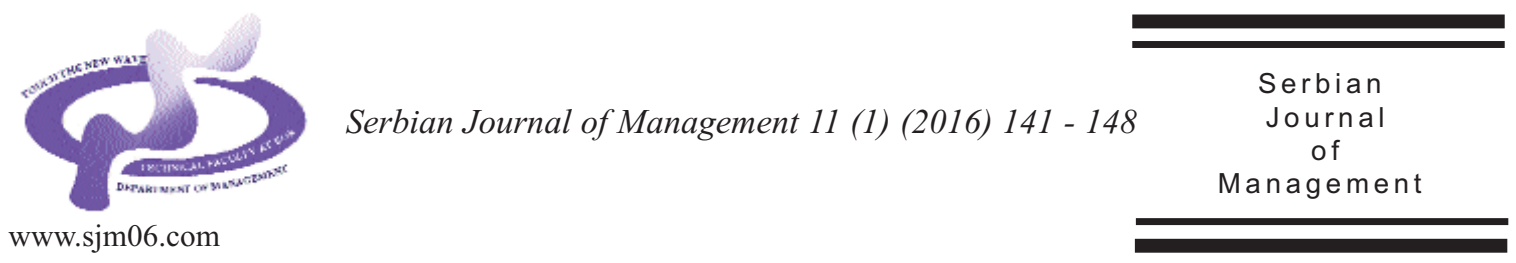

\title{
A STRUCTURAL EQUATION MODEL-II FOR WORK-LIFE BALANCE OF IT PROFESSIONALS IN CHENNAI
}

\author{
Rashida A. Banu* \\ Post-Graduate Department of Commerce, Stella Maris College, Chennai 600 086, India
}

(Received 14 April 2015; accepted 22 September 2015)

\begin{abstract}
The study developed and tested a model of work life balance of IT professionals employing structural equation modeling (SEM) to analyze the relationship between work place support (WPS) and work interference with personal life (WIPL), personal life interference with work (PLIW), satisfaction with work-life balance (SWLB) and improved effectiveness at work (IEW). The model fit the data well and hypotheses are generally supported. WPS and SWLB are negatively related to WIPL and PLIW. However, there is a positive relationship between SWLB and IEW.
\end{abstract}

Keywords: work place support, work life balance, SEM model, IT professionals

\section{INTRODUCTION}

In the recent years, it is being realized that life involves multiple domains and not restricted to the domains of work and family only. Kirchmeyer (2000) defined a balanced life as achieving satisfying experiences in all life domains. Kirchmeyer went on to be more prescriptive, stating that to achieve satisfying experiences in all life domains requires personal resources like energy, time and commitment to be well distributed across domains. Although definitions and explanations vary, work/life balance is generally associated with equilibrium, or maintaining an overall sense of harmony in life (Clarke et al., 2004). On the basis of various theories of work life balance and conceptual models, multiple factors related to individual, work and family affect the work life balance of an individual and researchers too have employed broader terms

\footnotetext{
* Corresponding author: rashidabanutaj@gmail.com DOI:10.5937/sjm11-8062
} 
and terminologies. Jang (2008) employed structural equation modeling (SEM) to analyze the associations among the perceptions of workplace support, supervisory support, work-schedule flexibility, work-life balance, and personal well-being. Perceived workplace support and perceived supervisory support were reported as latent exogenous constructs and "boundary-spanning resources" (Jang, 2008). Work social support construct included the measures of coworker social support, emotional / informational / instrumental support from work, group cohesiveness, lack of personal support at work/non-support, leader/managerial support, level of work group support, mentor supportiveness, perceived organizational support, psychosocial support, supervisor support (Michel et al., 2009). Social support is conceptualized as the structure of relationships as well as the flow of resources provided by relationships. Literature suggests that support available in the work domain ranges from the organization itself, supervisors and peers (Chan, 2009). Seiger and Wiese (2009) reported social support as an antecedent of work-family conflicts. Different sources of social support were supervisors, co-workers, partners and other family members. Yildirim and Aycan (2008) examined social support both as a moderator and a main effect in the relationship among work demands, work-to-family conflict, and satisfaction with job and life. According to the authors, supervisory support was an important source of social support in coping with problems associated with work-tofamily conflict.

In terms of work-life balance, researchers have also noted that the adoption of a supportive workplace culture in companies may be an important variable (Appelbaum et al., 2005). Organizational and support from co-workers and supervisors have always been an influential variable for the study of work life balance issues. Previous studies demonstrated that, in order for employees to have better work life balance it is equally important that they get supportive work environment (Thompson et al., 1999; Allen, 2001; O'Driscoll et al., 2003). The objective of this paper is to analyze the associations among Work Place Support (WPS) (as resource) and consequences such as Work Interference with Personal Life (WIPL), Personal Life Interference with Work (PLIW), Satisfaction with Work-Life Balance (SWLB) and Improved Effectiveness at Work (IEW) and evolve a model to that effect.

\section{RESULTS AND DISCUSSION}

WPS refers to actions and work practices that are designed to facilitate workers' effectiveness and wellbeing. Work Place Support has two key functions. 1. Ensure workers' wellbeing (social/emotional support) and 2. Ensure workers are capable of effective performance (instrumental support). Social/emotional support refers to support that is focused on meeting workers' needs to feel valued, cared for, respected and liked. Instrumental support refers to support that provides workers with practical assistance in terms of their roles, responsibilities and tasks (Skinner, 2005). Resources are needed to deal with increasing demands and stress. All resources are finite and can be consumed. We have therefore included work environment support, organizational support, manager support, coworker support to define WPS (Banu \& Duraipandian, 2014) in our study. 
Table 1. Underlying hypotheses of model

\begin{tabular}{ll}
\hline Hypotheses No. & Hypotheses \\
\hline 1. Work Place Support $\rightarrow$ WIPL & H01=There is no significant relationship between Work Place \\
& Support and Work Interference with Personal Life \\
& H1=Work Place Support will negatively affect Work \\
& Interference with Personal Life \\
& H02=There is no significant relationship between Work Place \\
2. Work Place Support $\rightarrow$ PLIW & Support and Personal Life Interference with Work \\
& H2=Work Place Support will negatively affect Personal Life \\
& Interference with Work \\
& H03=There is no significant relationship between Work \\
& Interference with Personal Life and Satisfaction with Work- \\
& Life Balance \\
& H3=Work Interference with Personal Life will negatively affect \\
& Satisfaction with Work-Life Balance \\
& H04=There is no significant relationship between Personal Life \\
& Interference with Work and Satisfaction with Work-Life \\
& Balance \\
& H4=Personal Life Interference with Work will negatively affect \\
& Satisfaction with Work-Life Balance \\
& H05=There is no significant relationship between Satisfaction \\
& with Work-Life Balance and Improved Effectiveness at Work \\
& H5=Satisfaction with Work-Life Balance will positively affect \\
& (Improved)Effectiveness at Work \\
&
\end{tabular}

This study employed the methodology reported elsewhere (Banu, 2015). Table 1 presents the hypotheses in five causal paths to determine the relationships between the variables under consideration, namely, exogenous variables (WPS) and endogenous variables, (WIPL, PLIW, SWLB and IEW).

Beta values presented in Table 2 are path coefficients or standardized regression coefficients that indicate the direct effect of independent variable to direct variable. Standardized beta values are used to estimate the path coefficients (Noor, 2003). The single-headed arrows represent linear dependencies indicating the extent to which one variable (construct) is dependent on another (causal paths or relationships). The results presented in Table 2 indicate that the hypotheses $\mathrm{H} 1$ to $\mathrm{H} 5$ are statistically significant and in the hypothesized direction.
Thus these hypotheses are supported. Since there is significant relationship established in the hypothesized direction, the null hypotheses $\mathrm{H} 01$ to $\mathrm{H} 05$ in Table 1 are rejected.

Table 2. Testing of hypotheses using $\beta$ values

\begin{tabular}{ll}
\hline Hypothesized path & $\boldsymbol{\beta}$ values \\
\hline $\mathrm{H} 1: \mathrm{WPS} \rightarrow$ WIPL & -0.58 \\
$\mathrm{H} 2: \mathrm{WPS} \rightarrow \mathrm{PLIW}$ & -0.31 \\
$\mathrm{H} 3: \mathrm{WIPL} \rightarrow \mathrm{SWLB}$ & -0.36 \\
$\mathrm{H} 4: \mathrm{PLIW} \rightarrow \mathrm{SWLB}$ & -0.10 \\
$\mathrm{H} 5: \mathrm{SWLB} \rightarrow \mathrm{IEW}$ & 0.65 \\
\hline
\end{tabular}

To evaluate the structural model, goodness-of-fit indices are examined to assess if the hypothesized structural model fits the data. Table 3 presents the model fit indices.

Of primary interest in SEM is the extent to which a hypothesized data "fits", or in 
Table 3. Model fit indices

\begin{tabular}{llll}
\hline Name of Index & Value & Level of acceptance (Shammout, 2007) & $\begin{array}{l}\text { Does it meet the } \\
\text { acceptance? }\end{array}$ \\
\hline $\mathrm{X}^{2}$ /df (Hair et al., 1995) & 2.148 & $\begin{array}{l}1.0 \leq x^{2} / \mathrm{df} \leq 5, \text { Lower limit is } 1.0 \text {, upper limit is } \\
3.0 \text { or as high as } 5\end{array}$ & yes \\
GFI & 0.931 & $\begin{array}{l}0.90 \text { or greater, value close to } 0 \text { indicates a poor fit, } \\
\text { while value close to } 1 \text { indicates a perfect fit }\end{array}$ & yes \\
RMSEA (Kline, 2005) & 0.067 & between 0.05 and 0.080 & yes \\
AGFI & 0.875 & $\begin{array}{l}\text { value close to } 0 \text { indicates a poor fit, } \\
\text { while value close to } 1 \text { indicates a perfect fit }\end{array}$ & yes \\
TLI & 0.882 & 0.90 or greater & yes \\
NFI & 0.93 & $>0.90$ & yes \\
\hline CFI & 0.96 & &
\end{tabular}

$\mathrm{X}^{2} / \mathrm{df}=$ Normed Chi-square (Parsimonious fit indices), GFI = Goodness of Fit (Absolute fit indices), RMSEA = Root Mean Square Error of Approximation (Absolute fit indices), AGFI = Adjusted Goodness of Fit (Inremental fit indices), TLI = Tuker-Lewis Index (Incremental indices), NFI = Normed Fit (Incremental fit), CFI = Comparative (Incremental fit).

other words, adequately describes the sample data. The model fitting process involves determining the goodness-of fit between the hypothesized model and the sample data (Jang, 2008). Goodness of fit indicates how well the specified model reproduces the observed covariance matrix among the indicator items (i.e. the similarity of the observed and estimated covariance matrices). There are many indices provided by SEM, although there is no agreement among scholars as to which fit indices should be reported (Shammout, 2007).

A range of acceptable values for the $\mathrm{X} 2 / \mathrm{df}$ ratio have been suggested, ranging from less than 2.0 (Bollen, 1989; Hair et al., 1995; Tabachnick \& Fidell, 2001), through less than 3.0 (Carmines \& McIver, 1981), to more liberal limits of less than 5.0 (Wheaton et al., 1977). RMSEA assists in correcting the tendency of chi-square to reject specified models. The general rule of thumb is that when RMSEA $\leq 0.10$, the fit is acceptable (Kline, 2005). While Holmes-Smith et al. (2006) recommend that RMSEA should be less than 0.05, MacCallum and Browne
(1993) suggest a value of up to 1.0 as reasonable. However, it has been found that a value ranging from 0.05 to 0.08 is commonly acceptable (Hair et al., 1995).

Acceptable model fit is indicated by a CFI value of 0.90 or greater (Hair et al., 1995; Hu \& Bentler, 1999). Similarly, alternative measures of fit, such as the NFI, the GFI are considered acceptable if above $0.90(\mathrm{Hu} \&$ Bentler, 1999; Kaplan, 2000). Similar to GFI, AGFI measure range from 0 (indicating a poor fit) to 1 (indicating a perfect fit), where a recommended level of acceptance is 0.90 (Hair et al.,1995). TLI is known as a non normed fit index (NNFI) (Marsh et al., 1988; Hair et al., 1995). TLI combines a measure of parsimonious into a comparative index between the proposed or hypothesized and null models, resulting in values ranging from 0 (not fit at all) to 1 (perfect fit).

The acceptable indices (Fisher-McAuley et al., 2003; Jang, 2008; Shammout, 2007) for goodness-of-fit demonstrate that this model fits the data adequately. Accordingly, the structural model-II is presented in Figure 1. 


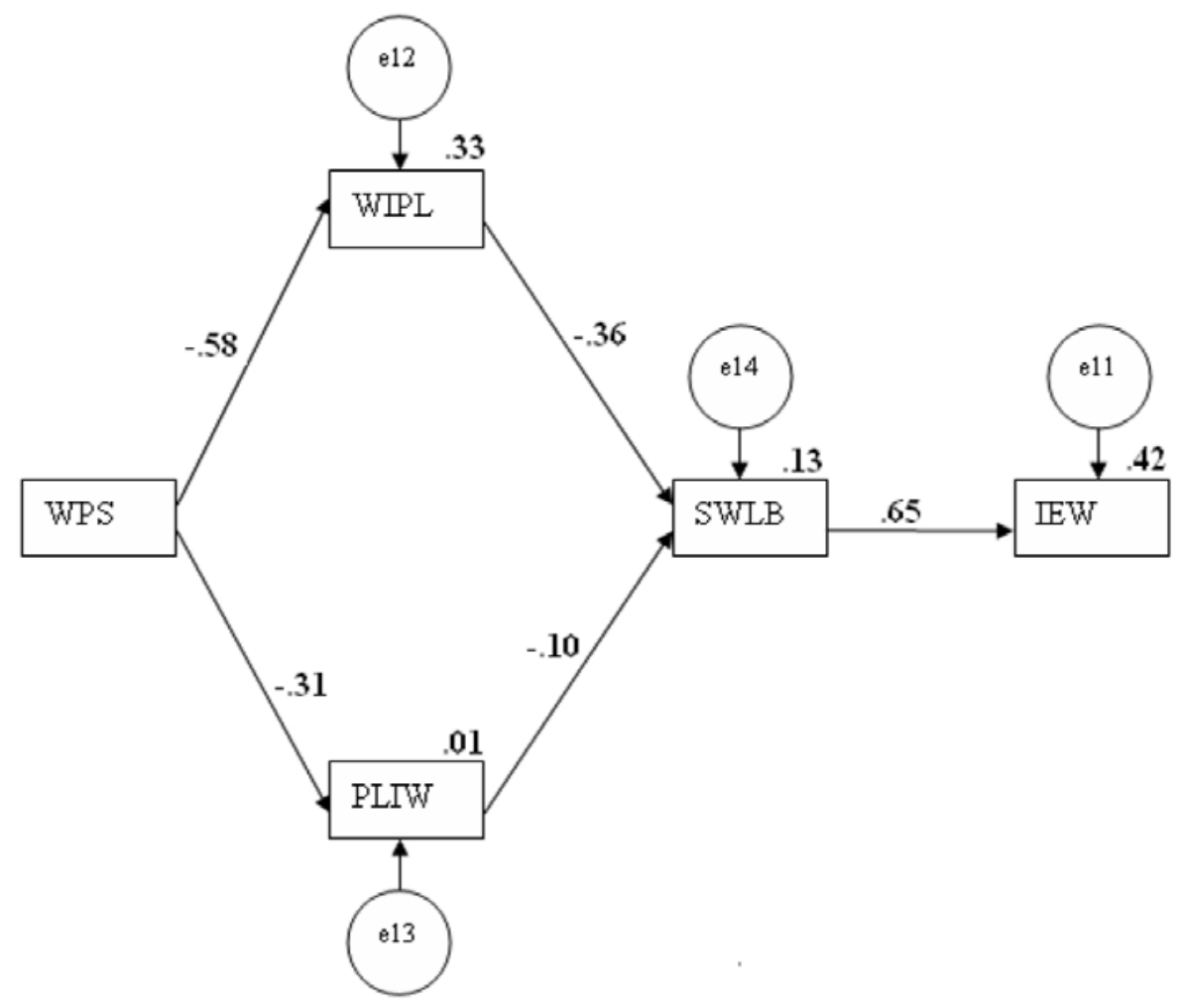

WPS $=$ work place support, WIPL=work interference with personal life, PLIW=personal life interference with work, SWLB=satisfaction with work life balance, IEW=Improved effectiveness at work.

Figure 1. Structural model-II

The regression coefficient for the path from Work Place Support to Work Interference with Personal life (WIPL) is negative $(\beta=-0.58)$ which indicates that when Work Place Support increases, Work Interference with Personal Life (WIPL) decreases. Similarly, the path from Work Place Support to Personal Life Interference with Work (PLIW) is negative $(\beta-0.31)$ which indicates that Work Place Support has impact over Personal Life Interference with Work (PLIW) and the magnitude of impact is less when compared to the impact of work place support on work interference with personal life. The path from Work Interference with Personal Life (WIPL) to Satisfaction with Work-Life Balance (SWLB) is negative $(\beta=-0.36)$ which indicates that when Work Interference with
Personal Life (WIPL) increases, Satisfaction with Work-Life Balance (SWLB) declines; similarly, when Personal Life Interference with Work (PLIW) increases, Satisfaction with Work-Life Balance (SWLB) declines as the path from Personal Life Interference with Work (PLIW) to Satisfaction with Work-Life Balance (SWLB) is negative ( $\beta=$ $-0.10)$. In spite of negative relationship between WIPL and SWLB and negative relationship between PLIW and SWLB, there is a positive relationship $(\beta=0.65)$ between SWLB and IEW. These findings support that over and above the negative effects of WIPL and PLIW, employees appeared to be satisfied with Work Life Balance as there is significant relationship between SWLB and IEW. 


\section{CONCLUSIONS}

It is identified through this work that those who had satisfactory work-life balance with the assistance of the policies implemented by the employing organization, tend to be more effective at work. When employees are not satisfied with their job and are not able to balance between the two domains of work and family, they tend to withdraw from their work related activities. Hence managers must not only have a theoretical understanding of work-life balance, conflict and enrichment, but also an understanding of the measurement tools to assess them. Only then can managers propose interventions to promote organizational and individual development, change initiatives and performance improvement. The solution lies with sound planning at individual level and initiatives from the organizations to aid productivity of the new age employees. It is believed that this study will contribute to assess the factors impacting the work life balance of IT professionals in Chennai and likely to aid more workplace interventions.

\section{References}

Allen, T.D. (2001). Family-supportive work environments: The role of organizational perceptions. Journal of Vocational Behavior, 58, $414-435$.

Appelbaum, E., Bailey, E., Berg, P., \& Kalleberg, A. (2005). Organizations and the intersection of work and family. In S. Ackroyd, R. Batt., \& P.S. Tolbert (ed.), The oxford handbook of work and organization, 52-73.

Banu, R.A., \& Duraipandian, K. (2014). Development of Instrument to Measure Work Life Balance of IT Professionals in Chennai. International Journal of Management, 5 (11), 21-33.

Banu, R.A. (2015). A Structural Equation Model-I for Work-Life Balance of IT

\title{
СТРУКТУРНИ МОДЕЛ - II УРАВНОТЕЖЕНА ПРИВАТНОГ ЖИВОТА И ПОСЛА КОД ИТ ПРОФЕСИОНАЛАЦА У ЧЕНЕЈУ
}

\section{A. Rashida Banu}

\begin{abstract}
Извод
У овој студији је развијен и тестиран модел уравнотежења приватног живота и посла код IT професионалаца, структурним моделом (SEM) је анализиран однос између подршке радног места (WPS) и утицаја посла на приватни живот (WIPL), утицаја приватног живота на посао (PLIW), задовољства уравнотежењем посла и приватног живота (SWLB) и побољшања ефикасности рада (IEW). Модел задовољавајуће фитује податке и хипотезе су углавном подржане. WPS и SWLB су у негативној релацији у односу на WIPL и PLIW. Међутим, постоји позитиван однос између SWLB и IEW.
\end{abstract}

Кључне речи: подршка радног места, уравнотеженје приватног живота и посла, SEM модел, IT професионалаци 
professionals in Chennai. European Journal of Business and Management, 7 (4), 221229.

Bollen, K.A. (1989). Structural Equations with Latent Variables, New York: Wiley.

Carmines, E.G., \& McIver, S.P. (1981). Analysing models with unobserved variables: Analysis of covariance structure. In G. w. Bohrnstedt \& E. F. Borgatta (Eds.), Social Measurement: Current Issues, Beverly Hills: Sage.

Chan, A.W. (2009). Antecedents and consequences of work-life balance: A multi sector exploration of the Malaysian workforce, School of Business Monash University Sunway campus, 18th November 2009. Available

at: file://C:/Documents\%20and\%20Settings/A dministrator/My\%20Documents/Downloads /Antecedents_and_consequences_of_work_1 ife_balance\%20(2).pdf.

Clarke, M., Koch, L., \& Hill, E. (2004). The work-family interface: Differentiating balance and fit. Family and Consumer Sciences Research Journal, 33 (2), 121-40.

Fisher-McAuley, G., Stanton, J.M., Jolton, J.A., \& Gavin, J. (2003). Modeling the Relationship between Work/Life Balance and Organizational Outcomes, poster presented at the Annual Conference of the Society for Industrial-Organizational Psychology, April 12, 2003, Orlando, FL. Available at: http://www.researchgate.net/publication/260 516221_Modeling_the_Relationship_betwe en_WorkLife_Balance_and_Organizational_ Outcomes.

Hair, J.F., Anderson, R.E., Tatham, R.L., \& Black, W.C. (1995). Multivariate Data Analysis with Readings (4th ed.). Englewood Cliffs, NJ: Prentice Hall.

Holmes-Smith, P., Coote, L., \& Cunningham, E. (2006). Structural Equation
Modeling: From the Fundamentals to Advanced Topics. Melbourne: $\backslash$ SREAMS.

Hu, L., \& Bentler, P.M. (1999). Cutoff criteria for fit indices in covariance structure analysis: Conventional versus new alternatives. Structural Equation Modeling, 6 (1), 1-55.

Jang, S.J. (2008). Relationships among Perceived Work-Life Balance, Resources, and the Well-Being of Working Parents, Dissertation, Graduate School-New Brunswick Rutgers, The State University of New Jersey, January 2008. Available at: https://rucore.libraries.rutgers.edu/rutgerslib/24264/pdf/1/

Kaplan, D. (2000). Structural equation modeling: Foundations and extensions, Thousand Oaks, CA: Sage.

Kirchmeyer, C. (2000). Work-life initiatives: Greed or benevolence regarding workers' time? In C.L. Cooper \& D.M. Rousseau (Eds.), Trends in Organizational Behavior. Chichester, UK: Wiley, 79-93.

Kline, R.B. (2005). Principles and practice of structural equation modeling, (2nd ed.), New York: The Guillford Press.

MacCallum, R.C., \& Browne, M.W. (1993). The use of causal indicators in covariance structure models: Some practice issues. Psychological Bulletin, 114 (3), 533541.

Marsh, H.W., Balla, J.R., \& McDonald, R.P. (1988). Goodness-of-fit indexes in confirmatory factor analysis: The effect of sample size. Psychological Bulletin, 103 (3), 391-410.

Michel, J.S., Mitchelson, J.K., Kotrba, L.M., LeBreton, J.M., \& Baltes, B.B. (2009). A Comparative test of work-family conflict models and critical examination of workfamily linkages. Journal of Vocational Behaviour, 74, 199-218.

Noor, N.M. (2003). Work- and family- 
related variables, work-family conflict and women's well-being: some observations, Community, Work \& Family, 6 (3), 297-319.

O'Driscoll, M.P., Poelmans, S., Kalliath, T., Allen, T.D., Cooper, C.L., \& Sanchez, J.L. (2003). Family responsive interventions, perceived organizational and supervisor support, work-family conflict and psychological strain. International Journal of Stress Management, 10, 326-344.

Seiger, C.P., \& Wiese, B.S. (2009). Social support from work and family domains as an antecedent or moderator of work-family conflicts? Journal of Vocational Behaviour, 75, 26-37.

Shammout, A.B. (2007). Evaluating an Extended Relationship Marketing Model for Arab Guests of Five-Star Hotels, Thesis, December 2007, School of Hospitality, Tourism and Marketing, Faculty of Business and Law, Victoria University, Melbourne, pp130-132. Available at: http://wallaby.vu.edu.au/adt V V U T / u p loads / a p p roved/a d t VVUT20080408.100446/public/02whole.pd f.

Skinner, N. (2005). Workplace Support. In N. Skinner, A.M. Roche, J. O'Connor, Y. Pollard, \& C. Todd (Eds.), Workforce Development TIPS (Theory Into Practice Strategies): A Resource Kit for the Alcohol and Other Drugs Field. National Centre for Education and Training on Addiction (NCETA), Flinders University, Adelaide, Australia.

Tabachnick, B.G., \& Fidell, L.S. (2001). Using Multivariate Statistics (4th ed.). Boston: Allyn and Bacon.

Thompson, C.A., Beauvais, L.L., \& Lyness, K.S. (1999). When work-family benefits are not enough: The influence of work-family culture on benefit utilization, organizational attachment and work-family conflict. Journal of Vocational Behavior, 54, 392-415.

Wheaton, B., Muthen, B., Alwin, D.F., \& Summer, G.F. (1977). Assessing reliability and stability in panel models. In D. R. Heise (Ed.), Sociological Methodology, (pp. 84136). San Francisco: Jossy-Bass.

Yildirim, D., \& Aycan, Z. (2008). Nurses' work demands and work-family conflict: A questionnaire survey. International Journal of Nursing Studies, 45 (9), 1366-1378. 